\title{
Assessment of the Fiscal Performance of Bee Keeping for Employment Generation and Poverty Reduction in Osun State, Nigeria
}

\author{
Adebo, G. M. \& Osundare, F. O. \\ Department of Agricultural Economics and Extension Services, \\ Ekiti State University,Ado Ekiti,Nigeria \\ E-mail: grace.adebo@eksu.edu.ng
}

Received: July 18, 2015

Accepted: August 2, 2015

doi:10.5296/jas.v3i2.8180

URL: http://dx.doi.org/10.5296/jas.v3i2.8180

\begin{abstract}
Beekeeping is a new venture in recent times that has the potential of improving the livelihoods of the Nigeria citizenry. A good proportion of youth and adults engaged in beekeeping. The study was embarked upon to investigate the fiscal performance of beekeeping as a possibility of reducing youth unemployment and alleviating poverty among the citizenry. Specifically, the study described the socio-economic variables of beekeepers income generating potentials of the enterprise, measured the economic efficiency and identified the constraints to honey beekeeping in the study area. A structured questionnaire was used to collect data from 120 respondents' purposively selected using a snowballing technique. The data collected was analyzed using Frequency counts and percentages, as well as profitability analysis and efficiency ratios. Results showed that honey beekeeping was carried out mostly by young, enlightened male respondents on a part-time basis. Most of them were members of the beekeeping association. The result also showed that the gross margin derived from Beekeeping was N16, 306, which constituted 93.68\% of the total revenue. Also, the Expense Structure Ratio (ESR), Benefits Cost Ratio (BCR) Rate of Return, Gross ratio (GR) Economic Efficiency (EE) was 0.79, 2.30, 2.30, 0.69 and 2.30 respectively. All the efficiency ratios indicated that beekeeping was profitable and worth venturing. The major constraints to Beekeeping in the study area were disturbance by farmers through some farm practices such as clearing, spraying of insecticides, hunting, fetching of firewood and felling trees as well as by cattle ranchers and climate variability.
\end{abstract}

Keywords: Beekeeping, Employment Generation, fiscal performance, profitability, livelihood strategy 


\section{Introduction}

Bees are the predominant and most economically important group of pollinators in most geographical regions. The Food and Agriculture Organization of the United Nations (FAO) estimates that out of some 100 crop species that provide $90 \%$ of food worldwide, 71 of these are bee-pollinated. In Europe alone, $84 \%$ of the 264 crop species are animal pollinated and 4 000 vegetable varieties exist" (UNEP, 2010). 'Honey is the natural sweet substance produced by Apis mellifera bees from the nectar of plants or from secretions of living parts of plants or excretions of plant-sucking insects on the living parts of plants, which the bees collect, transform by combining with specific substances of their own, deposit, dehydrate, store and leave in honeycombs to ripen and mature' (European Commission, 2001). The significance of Honey, as summarized by FAO (1990) shows that: honey has antioxidant and bacteria properties which improves digestive system and fight against diseases. It possesses carcinogen that prevents anti-tumour properties, regarded as anticancer. It is used as a natural cure for wounds, burns, and cuts. Honey has anti-bacteria properties that prevent infection and functions as anti-inflammatory agent thereby reducing swelling and pain. Honey also has anti- oxidant which reduces cholesterol thereby reducing heart diseases. Bee venom is used in treating arthritis and other inflammatory disorders. Honey can be used in treating digestive problems such as indigestion, stomach ulcer, and gastroenteritis. Honey can be used in increasing milk production and reducing acetonemia in cattle as well as making of rat and mice repellents. It is used widely in the manufacture of facial cleaners and hand lotion. The medicinal efficiency of honey has initiated a new and highly promising branch of medicine called "Apitherapy" with the term "API" from apis mellifera (honeybee). According to Amy and Echazarreta, (1996), the desirable features of honey on treating health challenges was the ease of administration for the treatment of wounds and the absence of antibiotic resistance as found with conventional antibiotics. It also lacks side effects in alleviating gastric pain and shortening the duration of diarrhea.

The high usefulness of bee and honey enhanced its production in large quantity in most parts of the world. For instance, FAOSTAT, (2012) indicated the top ten countries producing Honey worldwide and the quantities produced. The countries are China (400 000 tons), Turkey and the USA (80 000 tons each), Ukraine (70 000 tons), Argentina (60 000 tons), Mexico and Ethiopia (55 000 tons each), Russia and Iran (50 000 tons each) and India (40 000 tons) (FAOSTAT, 2012).

Although traditional beekeeping has long age history in Nigeria, however, Beekeeping as an enterprise is a relatively new enterprise in the nation. Currently, people are agitating for the diversification of the Nigeria economy and employment generation for the teaming youth populace. Beekeeping as an enterprise has proven the capability of being used for different purposes and thus can generate employment for the youths. More also, it has the potential of improving farmer's income and increase foreign exchange earnings of the country (Ojeleye, 1999). According to Adebo \& Ajiboye (2014), the issue of poverty is still prevalent in rural Nigeria, and there is urgent need to proffer solutions to it. They recommend that youth empowerment programs should focus on commercial agriculture rather than subsistence agriculture. Beekeeping on a large scale could go a long way in reducing poverty and youth 
unemployment in Nigeria.

The knowledge of the import of beekeeping makes the Nigerian government through the Agricultural Development Programme (ADP) to boost its production. Parts of the efforts made by the government includes: extension agents' visitation to honey farmers; organization of regular workshops on beekeeping; provision of modern equipment, improving honey marketing through improved contact with consumers; introduction of modern honey production techniques and the integration of beekeeping into rubber plantation establishment in rubber research institute (RRI) of Nigeria (Ojeleye, 1999).

A good number of farmers and youth across the country and especially in Osun state have been involved in Beekeeping over the years. Most of them belong to the beekeeping association and participated in the training programs organized by the ADP. However, there is a dearth of information on the performance of the beekeeping enterprise as a livelihood strategy in Osun state; hence the study is set to provide answers to some questions. Some of which are: what are the socioeconomic characteristics of beekeepers in the Osun state of Nigeria? How do they see the beekeeping enterprise? Do they take it as a full-time or part-time job? What is the scale of beekeeping production? Is the enterprise profitable? What are the costs and revenue structure of the enterprise? Is the enterprise efficient? The answers to these questions would prove if beekeeping as an enterprise could be an effective livelihoods strategy for youth empowerment and poverty alleviation in Nigeria.

\section{Methodology}

The study was carried out in Osun State, Nigeria. A multi- stage sampling was used in selecting the respondents for the study. The first stage involves a random selection of four out of 18 Local Government Areas (LGAs) in Osun state. The second stage involves a random selection of six villages from each LGA. The last stage involves the selection of five beekeepers from each village using a snowballing technique. Thus, a total of 120 respondents were selected and utilized for the study. A structured interview schedule was used to collect data while descriptive statistics, budgetary technique, and efficiency ratio were used in data analysis. The budgetary analysis was calculated using the model expressed as follows:

$$
\begin{gathered}
\text { NFI }=\text { GI }- \text { TC }(1) \\
\text { TC }=\text { TVC }+ \text { TFC }(2) \\
\text { Where: } \\
\text { NFI = Net Farm Income (N)/ Colony. } \\
\text { GI = Gross Income (N)/ Colony. } \\
\text { TC = Total cost }(\mathrm{N}) / \text { Colony. } \\
\text { TVC }=\text { Total variable costs }(\mathrm{N}) / \text { Colony } \\
\text { TFC }=\text { Total fixed costs }(\mathrm{N}) / \text { Colony }
\end{gathered}
$$

The profit $(\pi)$ analysis equation is given as: 


$$
\pi=\mathrm{TR}-\mathrm{TVC}
$$

Wherer $\pi=$ Profit from the sales of honey and bee wax

$$
\mathrm{TR}=\text { Total Revenue }
$$

TVC $=$ Total Variable Cost

The Expense ratio is the measure of an investment fund's costs of operation as a percentage of its total asset. The expense ratio for beekeeping is calculated by dividing the fund's total cost of beekeeping by its total assets

The Benefit cost ratio is gotten by dividing the present worth of benefit by the present worth of cost. If the BCR is equal or greater than one then the business is beneficial

Benefit-cost ratio $\mathrm{B} / \mathrm{C}=\mathrm{PW}$ of benefit/PW of cost $\geq 1$. (Rijiravanich, 2010).

The return on investment is calculated by subtracting the cost of investment from the gains from investment and divide by the cost of investment

$\mathrm{ROI}=\underline{\text { Gains from investment- cost of investment }}$

\section{Cost of investment}

Gross profit ratio (GP ratio) is calculated by dividing the gross profit from beekeeping by its net sales

Gross profit ratio $=\underline{\text { Gross profit }}$

Net sales

The efficiency ratio of beekeeping is calculated by using noninterest expense divided by total revenue less interest expense.

\section{Results and Discussion}

a) Socioeconomic Characteristics of the Respondents

Data in Table 1 shows that the respondents belong to different age brackets. However, $90.1 \%$ of them were below 45 years of age and had few years of beekeeping experience. Almost all the respondents $(98.5 \%)$ kept honey bees on a part- time basis to supplement other farm income. The system of beekeeping is contrary to what obtains in Turkey where beekeeping is the main source of income to over 68 percent of the beekeepers who own more than 160 colonies (Hasan \& Karaman2010). The majority (62.5\%) of the beekeepers were male, married and mostly literates. The domination of beekeeping by married men might probably be due to the skills required in handling bees and the fear of the female gender from being stung by the bees. More than half of the beekeepers claimed membership of Honey Producer Association of Nigeria. It is a reflection of governments' intervention in honey production in Nigeria as well as their educational status. In terms of the number of colonies owned. Table 1 also shows that $37.5,50.0 \& 12.50$ percent of the respondents owned $<20,21-40$ and above 
40 colonies respectively. The mean number of colony owned was 32.5.The average number of colony owned is relatively small when compared to Turkey. The average number of colony owned by a farmer in Turkey was 168.40 (Hasan \& Karaman, 2010), and that of Vietnam was 200-300 Nguyen (2010). It could be affirmed that beekeeping in Osun state is relatively on a small scale. Despite the fact that Muhammad, et al. (2006) reveals that beekeeping has higher economic efficiency than most crops grown in the Adamawa state of Nigeria, beekeeping is still at low ebb in most states in the country (Muhammad et al, 2006 \& Tijani et al., 2011). The low production is a reflection of the fact that most of the people took beekeeping as a part time occupation and the low level of awareness of the livelihood's transformative potentials of the bee venture. Also, 14.17 percent of the respondents earn less than N100 000 from beekeeping, and 26.67percent earned between N101-200.00 naira from beekeeping. About 40 percent earned between N201 000.00- 300 000.00, 10 percent earned between 301 000.00-400 000 annually while a few (9.16\%) earned above N400 000.00 from beekeeping annually. The mean annual income was N279 054.04. The annual income from Beekeeping compares relatively well with that of palm oil in Ekiti state whose mean annual income for 2011 was N 275000 as indicated by Adebo et al., (2014). It was also above the annual income from rice maize, sorghum and sugarcane, groundnut and millet in Adamawa state as reported by Muhammad et al. (2006). Thus, it could be said that the earnings from beekeeping is relatively high and could sustain the livelihoods of farmers if the scale of production is increased. More also, Bradbear (2010) affirmed in his study that beekeeping is environmentally sustainable and a good livelihood practice for many people around the world. 


\section{Ml Macrothink}

Table 1. Socio-Economic Characteristics of the Respondents

\begin{tabular}{|c|c|c|}
\hline Variable & Frequency & Percentage \\
\hline \multicolumn{3}{|l|}{ Age } \\
\hline $20-29$ & 21 & 17.5 \\
\hline $30-39$ & 57 & 47.5 \\
\hline $40-49$ & 30 & 25.0 \\
\hline $50-59$ & 10 & 8.33 \\
\hline$\geq 60$ & 02 & 1.67 \\
\hline \multicolumn{3}{|l|}{ Sex } \\
\hline Male & 99 & 82.5 \\
\hline Female & 21 & 17.5 \\
\hline \multicolumn{3}{|l|}{ Marital status } \\
\hline Single & 30 & 20.0 \\
\hline Married & 75 & 62.5 \\
\hline Widow/widower & 15 & 10.0 \\
\hline \multicolumn{3}{|l|}{ Level of education } \\
\hline No formal education & 08 & 6.67 \\
\hline Primary education & 21 & 17.5 \\
\hline Secondary education & 20 & 16.67 \\
\hline Tertiary education & 67 & 55.83 \\
\hline Non-formal education & 04 & 3.33 \\
\hline \multicolumn{3}{|l|}{ Bee keeping experience } \\
\hline $\begin{array}{l}\leq 4 \text { years } \\
5-9 \text { vears }\end{array}$ & 42 & $\begin{array}{l}35.0 \\
425\end{array}$ \\
\hline $\begin{array}{l}5-9 \text { years } \\
10-14 \text { years }\end{array}$ & $\begin{array}{l}31 \\
25\end{array}$ & $\begin{array}{l}42.5 \\
20.83\end{array}$ \\
\hline$\geq 15$ years & 02 & 1.67 \\
\hline \multicolumn{3}{|l|}{ Membership of Bee keeping Association } \\
\hline Yes & 68 & 56.67 \\
\hline \multirow{2}{*}{\multicolumn{3}{|c|}{$\begin{array}{l}\text { No of colony owned } \\
\text { No }\end{array}$}} \\
\hline & & \\
\hline$\leq 20$ & 45 & 37.5 \\
\hline $21-40$ & 60 & 50.00 \\
\hline$>40$ & 15 & 12.50 \\
\hline \multicolumn{3}{|l|}{ Annual income from Beekeeping (A) } \\
\hline$<100000.00$ & 17 & 14.17 \\
\hline $101000.00-200000.00$ & 32 & 26.67 \\
\hline $201000.00-300000.00$ & 48 & 40.00 \\
\hline $301000.00-400000$ & 12 & 10.00 \\
\hline 400000.00 & 11 & 9.16 \\
\hline
\end{tabular}

Source: Field Survey, 2013

b) Profitability Analysis

Data in Table 2 shows that the total variable cost for beekeeping in Osun state was 4173.20 while the total fixed cost was 1100.00 . The total cost was 5173.20. The average total revenue resulting from the sale of honey and bee wax was N 17406 while the Gross Margin and the Net farm income were $16306.00 \& 12132.80$ respectively. The gross margin accounted for 93.68 percent of the total revenues. It shows that beekeeping is a profitable enterprise in Osun state, Nigeria. In a similar study carried out in Edo State by Atamonokhai (2002), the gross margin for honey from bee keeping accounted for $95.4 \%$ of the total revenue. The findings are supported by the reports of Tijani et al. (2011) Folayan \& Bifarin (2013) and Famuyide et al. (2014). Their findings indicated that beekeeping is a profitable venture in Chibok Local Government area of Borno state as well as in Oyo and Edo states, Nigeria. In essence, beekeeping as a profitable venture could be used as empowerment and poverty reduction strategy in Nigeria. 


\section{Al Macrothink}

Table 2. Estimated Costs and Returns per colony in Beekeeping

\begin{tabular}{lcl}
\hline Item & Mean Value & Percentage \\
\hline Gross revenue: & 17406.00 & \\
Fixed input costs: & 352.00 & 32.00 \\
Beehives & 198.00 & 18.00 \\
Bucket & 203.00 & 18.45 \\
Torch light & 347.00 & 31.55 \\
Ropes & 1100.00 & 100.00 \\
TFC & & \\
Variable input costs: & 1000.00 & 23.96 \\
Hired labour & 1050.80 & 25.16 \\
Baiting materials & 250.00 & 5.99 \\
Control of pest and predators & 450.25 & 10.79 \\
Batteries & 750.02 & 17.97 \\
Corn stock & 50.00 & 1.20 \\
Matches & 622.93 & 14.93 \\
Contingencies & 4173.20 & 100.00 \\
TVC & 5273.20 & \\
TFC+TVC & 16306.00 & \\
GM & 12132.8 & \\
Net farm income & & 79.68 \\
$\%$ GM/TR & & 69.74 \\
$\%$ TVC/TC & \\
\%NP/TR & & \\
\hline
\end{tabular}

c) Efficiency of beekeeping

Data in figure 1 shows the Efficiency Ratio (ER) for beekeeping in Osun state. The Expense Structure Ratios (ESR) and Benefit Cost Ratio (BCR) were 0.21 and 2.3 respectively. The ESR of 0.21 implies that about $21 \%$ of the total cost was made up of fixed component. The low ESR gives room for honey beekeepers to adjust quickly to varying market conditions. Also, the Rate of Returns (ROR) was 2.3. The ROR of 2.30 shows that for every N 1.00 investment on beekeeping, the farmer earns N 2.30 profit. Likewise, the Gross Ratio (GR) of 0.69 and Economic Efficiency (EE) of 2.30 indicated that honey bee keeping was an economically viable enterprise worth venturing into in the study area.

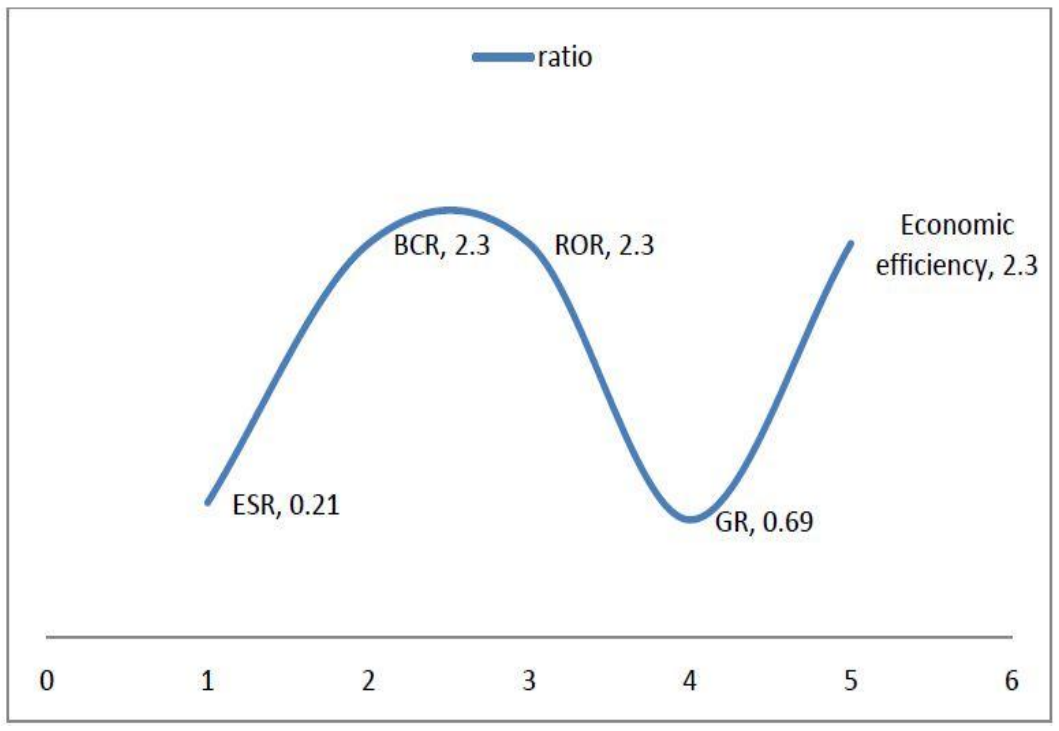

Figure 1. Efficiency Ratio of Honey Beekeeping in Osun State 


\section{Macrothink}

Data in figure 2 shows that 2.3 percent of the respondents suffered from land tenure problems, 31.55 percent were disturbed by human activities. Also, 24.76 percent reported disturbance by cattle ranchers, 30.0 percent suffered from climate variability, and 18.32 percent were affected by pest and diseases while 8.74 percent suffered from reptiles attack. The major constraints to Beekeeping in Osun state were the disturbance by human activities and cattle ranchers as well as climate variability. All other factors recorded very low percentages. The villagers also disturbed the Bees through the agricultural activities when clearing, spraying of insecticides, hunting, fetching of firewood and felling trees.

The cattle ranchers disturbed the bees' farmland when feeding their cattle particularly during the dry season that coincides with the flowering period of plants. Their presence scares the bees thereby reducing the comb and honey produced. It supports the findings of Tirado (2013) that wild bees are threatened by many environmental factors, including lack of natural and semi-natural habitats and increased exposure to man-made chemicals. Also, Hasan \& Karaman (2010) discovered that high chemical usage in the hives was one of the major constraints to beekeeping in Turkey. However, it differs from the findings of Tijani et al. (2011) who identified theft and lack of credit as major impediments to beekeeping in Chibok Local Government area of Borno state in Nigeria. Also, Climate variability affects beekeeping, especially extremely high temperature could be very destructive during brooding. It also supports the findings of Adebo \& Sekumade (2013) that climate change constitutes major impediment to reducing farmers productivity in Ekiti and Ondo states of Nigeria

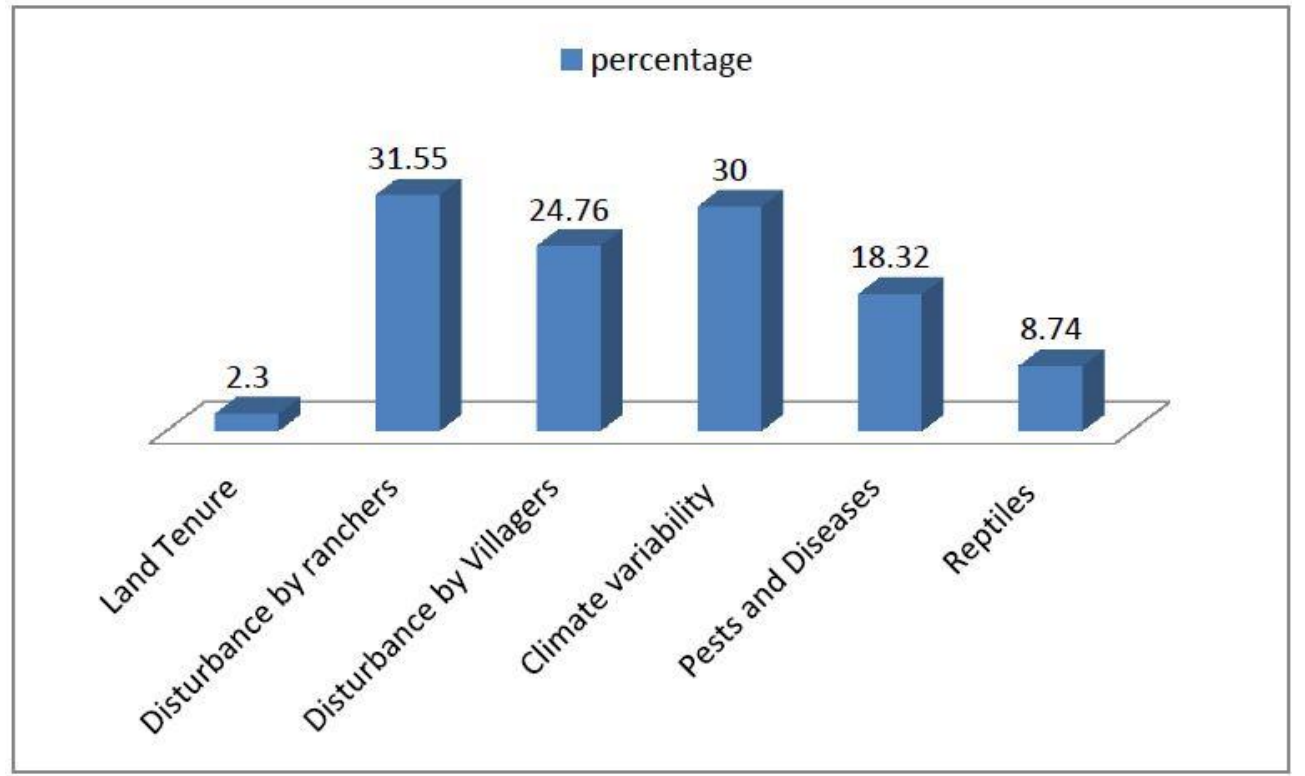

Figure 2. Constraints to beekeeping in Osun state

Source: Field survey, 2013

\section{Summary, Conclusion and Recommendations}

a) Summary

Beekeeping is a relatively new venture in Osun state, kept mostly on a part-time basis to supplement farm income. Beekeeping in Osun state is a male-dominated occupation, most of the producers are young, literate, and married. More than half 
of the beekeepers were members of Honey Producer Association of Nigeria. The mean number of colony owned per person was 24.2 while the mean annual income was $\mathrm{N} 279$ 054.04. The annual income from Beekeeping compares relatively well with that of other crops and is relatively high to sustain the livelihoods of farmers if the scale of production is increased.

The average total revenue resulting from the sales of honey and bee wax was N 17 406 while the Gross Margin and the Net farm income were 16, 306.00 $\& 12,132.80$ respectively. The gross margin accounted for 93.68 percent of the total revenues. The Expense Structure Ratios (ESR) and Benefit Cost Ratio (BCR) were 0.21 and 2.3 respectively. The Rate of Returns (ROR) was 2.3. The ROR of 2.30 shows that for every $\mathrm{N} 1.00$ investment on beekeeping, the farmer earns $\mathrm{N}$ 2.30 profit. Likewise, the Gross Ratio (GR) of 0.69 and Economic Efficiency (EE) of 2.30 indicated that honey bee keeping was an economically viable enterprise worth venturing into in the study area.

However, the major constraints to Beekeeping in Osun state were the disturbance by human activities and cattle ranchers as well as climate variability.

b) Conclusion

Beekeeping is not a major source of income for the producers. However, it is a profitable venture that could be used to could be used to generate employment and empower the youth. It is a veritable tool for poverty alleviation.

c) Recommendations

Based on the findings of the research, the study recommends that:

Farmers should be encouraged to increase the scale of production of beekeeping to enhance more income.

$>\quad$ They should make full utilization of the Honey Producers Association in obtaining loans and acquiring skills necessary to hurl them from small to medium and large scale beekeepers

$>$ Government policies on human and animal activities that could hinder bee production hould be enforced

$>$ The government and non-governmental Organizations should pay Special attention on climate change and the strategies to reduce the impact on agricultural production and beekeeping in the state

$>$ The female gender can be encouraged to engage in value addition to honey production to enhance their income

\section{Acknowledgement}

The contribution of Falusi Akinsola Oluseun to the collection of data used for this study is hereby acknowledged and appreciated 


\section{References}

Adebo, G. M., \& Ajiboye, A. (2014). Comparative Analysis of Poverty Level among Rural and Urban Farmers in Ekiti and Ondo States. Journal of Developing Countries Studies. The International Institute for Science, Technology and Education (IISTE), 4(20), 23-27.

Adebo, G. M., \& Sekumade, A. B. (2013). Climate Change and Adaptive Capacity of Women to Rural Water Supply in Ekiti State Nigeria. Academic Research International, 4(2), 386-399.

Adebo. G. M., Ayodele. O. J., Olowokere, K. (2015). Palm Oil Production as a Poverty Alleviation Strategy among Small-scale Farmers in Ekiti State, Nigeria. World Journal of Agricultural Research, 3(2), 43-48

Amy, E., Jeffrey, Carlos, M. E. (1996). Medical uses of honey Rev Biomed, 7, 43-49.

Atamonkhai, E. K. (2002). Economic Analysis of Honey Bee-Keeping in Edo State, Nigeria. Unpublished Thesis at the Department of Extension Farm Management, Federal College of Agriculture, Akure, Ondo State.

Brabear, N. (2010). Beekeeping Development-Why is success so difficult to achieve? International conference on Beekeeping Development and Honey Marketing, Hanoi Vietnam, 24

European Commission, (2001). Evaluation of the CAP measures related to apiculture Agriculture and Rural Development DG- Final Report. Directive 2001/110/EC

Famuyide, O.O., Adebayo, O. Owese, T., Azeez, F.A., Arabomen, O., Olugbire, O.O and Ojo, D (2014). Economic Contributions of Honey Production as a Means of Livelihood Strategy in Oyo State International Journal of Science and Technology, 3(1).

FAO. (1990). Food and Agriculture Organization of the United Nations Publications, Rome

FAOSTAT. (2012). Trends in World Honey production. the amounts produced by country and provide a view of the recent trend in production.

Folayan, J. A., \& Bifarin, J. O. (2013). Profitability analysis of honey production in Edo North Local Govt of Area of Edo State, Nigeria. Journal of Agricultural Economics and Development, 2(2), 60-64.

Hasan, V., \& Süleyman, K. (2010). Socio-economic analysis of beekeeping and the effects of beehive types on honey production African Journal of Agricultural Research, 5(22), 3003-3008. http://www.academicjournals.org/AJAR.

Muhammad, R. Ja'afar-Furo, A. S., \& Yusuf El-Sahab, H. (2006). A Comparative Analysis of Beekeeping and Crop Production in Adamawa State, Nigeria Apiacta , 41(2006), 44 -53

Nguyen, Q. T. (2010). Profitability of Apis Mellifera in Vietnam. University of Agriculture and Forestry, Thu Duc, Ho Chi Minh city, Vietnam

Ojeleye, B. (1999). Chemical Composition of Honey. The Beekeeper Journal, 1, 4-5.

Rijiravanich, V. (2010). Benefit Cost ratio. Siam University

Tijanil, B. A., Ala, A. L. Maikasuwa, M. A., \& Ganawa, N. (2011). Economic Analysis of Beekeeping in Chibok Local Government Area of Borno State,Nigeria. Nigerian Journal of Basic and Applied Science, 19(2), 285-292.http://www.ajol.info/index.php/njbas/index

Tirado, R. (2013). A review of factors that put pollinators and Agriculture in Europe at risk. Greenpeace research laboratory technical report 


\section{Macrothink}

Journal of Agricultural Studies

ISSN 2166-0379 2015, Vol. 3, No. 2

UNEP (2010). UNEP Emerging Issues: Global Honey Bee Colony Disorder and Other Threats to Insect Pollinators. United Nations Environment Programme.

\section{Copyright Disclaimer}

Copyright for this article is retained by the author(s), with first publication rights granted to the journal.

This is an open-access article distributed under the terms and conditions of the Creative Commons Attribution license (http://creativecommons.org/licenses/by/3.0/). 